\title{
Non-metric dental trait variation among local sites and regional groups of the Neolithic Jomon period, Japan
}

\author{
Hirofumi MATSUMURA ${ }^{1 *}$ \\ ${ }^{1}$ Department of Anatomy, Sapporo Medical University, S1W17, Sapporo, 060-8556 Japan
}

Received 2 December 2005; accepted 22 July 2006

\begin{abstract}
Inter-populational heterogeneity of the Neolithic Jomon hunter-gatherers of Japan was examined via 21 non-metric dental traits. Skeletal samples from nine local sites and five regional groups of the middle to final stages of the Jomon period were analyzed, and inter-site comparisons were made among five representative sites (Ubayama, Nakazuma, Ikawazu, Yoshiko, and Tsukumo). Statistically significant differences were found in $4 / 21$ traits in the inter-site comparisons, and in 5/21 traits in the inter-regional comparisons between the Hokkaido, Tohoku, Kanto, Tokai, and Sanyo groups. Smith's distances suggest that the inter-regional differences within the Jomon assemblages are minor when compared with differences from the non-Jomon samples such as the Yayoi immigrants, Kofun, and modern Japanese. Furthermore, examination of the wider geographical variation of the Jomon people (eastern versus western) revealed significant differences in only $2 / 21$ traits. Distance analysis showed that the eastern and western Jomon groups clustered together, and exhibited the greatest affinities with present-day Southeast Asians among comparable East Asian and Pacific population samples. The Jomon people can be collectively regarded as relatively homogeneous, within the broader context of East Asian and Pacific intra-population variation.
\end{abstract}

Key words: Jomon, non-metric dental traits, geographic variation

\section{Introduction}

The Jomon people were Neolithic hunter-gatherers that inhabited the Japanese archipelago from ca. $12000-13000$ BP to ca. 2300-2340 BP (e.g. Kondo and Matsu'ura, 2005; Yoneda et al., 2005). It is generally agreed, based on cranial and dental morphology, that Jomon period populations are direct ancestors of the Hokkaido Ainu (e.g. Howells, 1966; Turner, 1976; Brace and Nagai, 1982; Yamaguchi, 1982; Hanihara, 1985, 1991; Dodo, 1986; Mouri, 1986; Matsumura, 1989, 1994, 1995a, b; Dodo and Ishida, 1990; Pietrusewsky, 1994, 2004; Ossenberg et al., 2006). Geographical variation in Jomon period material has been investigated by several researchers and only minor differences have been found in the cranial morphology of samples dating from the middle to final Jomon periods (ca. 5000-2300 BP) (Ogata, 1981; Dodo, 1982; Yamaguchi, 1982; Mouri, 1986; Kondo, 1994). It is generally accepted that Jomon samples are, for the most part, collectively homogeneous.

Geographical variation of Jomon dental morphology has been investigated previously by the current author (Matsumura, 1989, 2000a, b). Although some significant variation was found in metric dental traits between local sites and regional groups, the differences were much smaller than those found between Jomon and modern Japanese samples. In other words, all Jomon samples share a common

* Corresponding author. e-mail: hiromura@sapmed.ac.jp phone: +81-11-611-2111; fax: +81-11-618-4288

Published online 31 October 2006

in J-STAGE (www.jstage.jst.go.jp) DOI: 10.1537/ase.051202 suite of dental metric features.

The aim of this paper is to examine non-metric dental trait variation comparing samples from nine local sites, five regional groups, and eastern and western Japan. In addition, the level of geographical variation among the Jomon population was assessed in comparison with several East Asian and Pacific populations compiled by large-scale geographical units.

\section{Materials and Methods}

The middle to final Jomon period (ca. 5000-2300 BP) samples analyzed in this study are summarized in Table 1 and Figure 1. The data set has been expanded from an earlier study (Matsumura, 1989) to include specimens from the Funadomari site on Rebun Island (Matsumura et al., 2001) and the Usumoshiri site in Date City; these additions have increased the sample size for the Hokkaido island regional group. The Kanto regional group has also been increased with the addition of new specimens from the Shimohta site (Hirata and Hoshino, 2003) and the Rokutsu site in Chiba Prefecture and the Nakazuma site in Ibaraki Prefecture (Matsumura, 1995a).

Twenty one non-metric dental traits were scored using protocols and criteria given in Matsumura (1995b). All traits were scored in both sexes on the basis of presence/absence to facilitate statistical comparisons, although males and females were combined given the low to minimal sexual dimorphism expected for these traits (Turner et al., 1991). Observations of non-metric traits were recorded for teeth on the right side or antimere substitutions when necessary. 
Table 1. The local sites of Jomon samples from the five regional groups examined

\begin{tabular}{|c|c|c|}
\hline Region & & Site \\
\hline \multirow[t]{3}{*}{ Eastern Japan } & Hokkaido (69) & $\begin{array}{l}\text { Bibi (5), Funadomari (18), Higashikushiro (2), Irie (5), Midorigaoka (11), Misawagawa (8), } \\
\text { Motowanishi (7), Takasago (11), Usumoshiri (2) }\end{array}$ \\
\hline & Tohoku (92) & $\begin{array}{l}\text { Ebishima (14), Hashimotogakoi (1), Hibiki (1), Hosoura (5), Kashikodokoro (1), Kitazakai (2), } \\
\text { Monzen (1), Nakazawahama (11), Ohbora (8), Sanganji (42), Satohama (1), Tsutsumi (5) }\end{array}$ \\
\hline & Kanto (214) & $\begin{array}{l}\text { Chidorikubo (3), Higashi (4), Horinouchi (4), Kaigarazaka (1), Kasori (20), Kosaku (1), Kuroya } \\
\text { (4), Mae (1), Mitsuzawa (4), Nakazuma (61), Rokutsu (7), Sanhanda (1), Shimohta (42), Shimon- } \\
\text { umabe (1), Soya (1), Ubayama (51), Uraga (2), Yoyama (6) }\end{array}$ \\
\hline \multirow[t]{2}{*}{ Western Japan } & Tokai (257) & $\begin{array}{l}\text { Hachiohji (1), Hayashinomine (2), Hobi (29), Ikawazu (59), Inariyama (32), Karekinomiya (14), } \\
\text { Motokariya (2), Narumi (1), Yahagi (2), Yazaki (8), Yoshiko (107) }\end{array}$ \\
\hline & Sanyo (110) & Hashima (7), Tsukumo (68), Tsubue (2), Yosekura (33) \\
\hline
\end{tabular}

The number of individuals of each sample is shown in parenthesis.

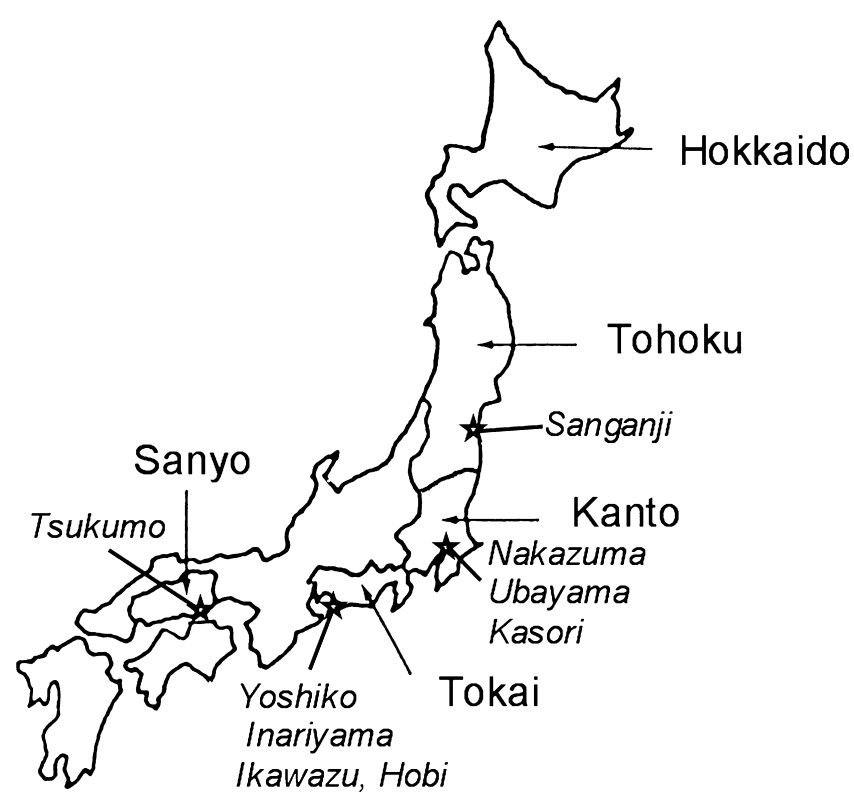

Figure 1. Names of places for inter-site and inter-regional comparisons used in the present study. Site names are shown in italics.

Initially, frequencies of the 21 non-metric traits were recorded for the larger samples (see Table 1) which include: Sanganji in Fukushima Prefecture (Hanihara et al., 1983); Ubayama (Koganei, 1932; Kondo, 1993, 1994; Mizushima et al., 2004) and Kasori (Suzuki et al., 1968; Mizushima et al., 2006) in Chiba Prefecture; Nakazuma in Ibaragi Prefecture (Matsumura, 1995a); Ikawazu (Suzuki et al., 1972; Ehara et al., 1985), Hobi (Suwa et al., 2003), Yoshiko (Kintaka, 1928) and Inariyama in Aichi Prefecture; and Tsukumo (Kiyono and Miyamoto, 1926) in Okayama Prefecture. All of these samples are dated to the Middle to Final Jomon period (ca. 5000-2300 BP). Comparisons were made between local sites, and groups were excluded if the sample size was small. Chi-square tests were used to evaluate the significance of variation in trait frequencies.

In the next stage of the study, the five regional groups (see Table 1) were compared to assess trait variation with respect to the large geographical units identified here as Hokkaido, Tohoku, Kanto, Tokai, and Sanyo districts. Biological rela- tionships among these regional samples were explored using Smith's distances (Berry and Berry, 1967), often referred to as 'mean measure of divergence' values, to evaluate population affinities based on the presence/absence frequencies of non-metric trait traits. The formula used here (modified by Hanihara, 1976) was:

$$
\mathrm{MMD}=\sum_{k=1}^{\mathrm{m}}\left\{\left(\theta_{i k}-\theta_{j k}\right)^{2}-\left[\left(1 / n_{i k}\right)+\left(1 / n_{j k}\right)\right]\right\} / m,
$$

where $\theta_{i k}$ is $\sin ^{-1}\left(1-2 p_{i k}\right)$ in the presence of trait $k$ in population $i, n_{i k}$ is the number of samples, and $m$ is the number of traits involved. In order to assess the degree of inter-regional group differences within the collective Jomon sample, distances from chronologically or ethnically different population samples such as the Yayoi immigrants, protohistoric Kofun, modern Japanese, and Hokkaido Ainu (data: Matsumura, 1990, 1995a, b) were computed simultaneously. The neighbor-joining method (Saitou and Nei, 1987) was applied to the matrix of Smith's distances to aid in the interpretation of inter-sample phenotypic variation.

In the final stage of the comparison, geographical variation was examined between eastern and western Japan. The eastern Jomon comprises the Hokkaido, Tohoku, and Kanto samples, and the western Jomon includes the Tokai and Sanyo samples. In order to assess the level of differences between the two Jomon groups, those affinities to the eight groups comprising large-scale units in East Asia and Pacific were evaluated using Smith's distances. These macroregional groups accord with the italicized names of the groups in Table 2. Matsumura and Hudson (2005) and Matsumura (2006) give the detail of these materials together with the data of the non-metric dental traits recorded.

\section{Results}

\section{Inter-site comparisons}

The frequencies of the 21 non-metric dental traits for nine local site samples are summarized in Table 3. Some of the local site samples display poor preservation of the anterior dentition (particularly the incisors and premolars), which affects the reliability of anterior tooth trait frequencies. Since the Ubayama, Nakazuma, Ikawazu, Yoshiko, and Tsukumo samples yield trait frequency data based on relatively large samples, significance tests were performed for 21 
Table 2. List of population samples from East Asia and Pacific for the macro-regional comparison

\begin{tabular}{|c|c|c|c|c|c|}
\hline Series & $n$ & Series & $n$ & Series & $n$ \\
\hline Prehistoric Southeast Asians & & Mainland Southeast Asians & & Hokkaido Ainu & \\
\hline Gua Cha & 20 & Malay & 81 & Hokkaido Ainu & 61 \\
\hline Guar Kepah & 27 & Thailanders & 102 & & \\
\hline Middle Holocene Flores & 9 & Laotians & 57 & Early and Modern Japanese & \\
\hline Bac Son & 17 & Vietnamese & 65 & Yayoi immigrants & 212 \\
\hline Da But & 46 & Cambodians & 17 & Kofun Japanese & 287 \\
\hline Early Holocene Laos & 12 & & & Kamakura Japanese & 364 \\
\hline Ban Kao (+ Lue) & 37 & Island Southeast Asians & & Edo Japanese & 254 \\
\hline Non Nok Tha & 15 & Philippines & 53 & Tokyo Japanese & 69 \\
\hline \multirow[t]{2}{*}{ Khok Phanom Di } & 2 & Negritos & 37 & & \\
\hline & & Dayak & 74 & Northeast Asians & \\
\hline Australians and Melanesians & & Sumatra Islanders & 41 & Northern Chinese & 149 \\
\hline Australian Aborigines & 101 & Lesser Sunda and Java & 20 & Urga Mongolians & 132 \\
\hline Loyalty Islanders & 62 & & & & \\
\hline New Britain Islanders & 188 & $\begin{array}{l}\text { Andaman Islanders } \\
\text { Andaman Islanders }\end{array}$ & 69 & & \\
\hline
\end{tabular}

For information of materials listed in this table, see Matsumura and Hudson (2005).

non-metric dental traits between these five local site samples. Significant differences were found in $4 / 21$ traits in these samples at $p<0.05$ including: De Terra's tubercle in the upper first premolars; hypocone reduction in the upper second molars; and an ' $\mathrm{X}$ ' groove pattern and hypoconulid reduction in the second mandibular molars (see Table 4).

\section{Inter-regional comparisons}

Frequencies of the 21 non-metric dental traits for the five regional samples are given in Table 5. Chi-square tests were carried out to examine the significance of inter-regional differences in each trait frequency (Table 6). Five traits display significant geographical differences at $p<0.05$ including: hypocone reduction in the upper second molars; a sixth cusp and a ' $Y$ ' groove pattern in the first mandibular molars; and an ' $\mathrm{X}$ ' groove pattern and hypoconulid reduction in the second mandibular molars.

Smith's distances were calculated using the 21 non-metric dental frequency data, together with the data from the Yayoi immigrants, protohistoric Kofun, modern Japanese, and Hokkaido Ainu (see Table 7). While the greatest intersample distance within the collective Jomon assemblage is between the Kanto and Sanyo samples, this value is smaller than distances between any Jomon samples and non-Jomon samples such as the Yayoi, Kofun, and Japanese.

The neighbor-joining method was applied to the distance matrix of Table 7 to generate an unrooted tree (see Figure 2). The five regional Jomon groups form a single major cluster together with the Ainu, while the Yayoi, Kofun, and modern Japanese are quite separate, and form another major cluster. In the Jomon cluster, the Sanyo group is furthest from the Hokkaido, while the Kanto and Tokai groups are located in an intermediate position. The Hokkaido Ainu are very close to the Jomon groups, particularly the Hokkaido Jomon people that lived in the same region.

\section{Macro-regional comparisons}

In the final stage of the comparison, the Jomon people were geographically compared between eastern and western
Japan. Table 8 gives the frequencies of the 21 non-metric dental traits in the eastern and western Jomon samples, and the results of the chi-square tests of significance between the two groups. Only two traits show significant geographical differences under the $5 \%$ level, i.e. hypocone reduction in the upper second molars, and an ' $X$ ' groove pattern in the mandibular second molars.

The affinities of the two Jomon samples with the other surrounding macro-regional populations were estimated by Smith's distances as given in Table 9, which were computed using the frequency data for 21 non-metric traits. Figure 3 represents an unrooted tree illustrated using the neighborjoining method. The western and eastern Jomon, closely tied with the Hokkaido Ainu, show close affinities to the Island and mainland Southeast Asians, but are very distant from the Northeast Asians and Andaman Islanders.

\section{Discussion}

In general, intra-ethnic group variation is minor in comparison with inter-ethnic group variation. When performing statistical comparisons using non-metric trait frequency data, the analysis requires adequate sample sizes to test inter-group variation within a single population such as the Jomon. Although data from the nine local site samples were given in the present study, inter-local site comparisons were made for only five groups. Even in sites with large dental assemblages, such as Ubayama, Nakazuma, Ikawazu, Yoshiko and Tsukumo sites, statistically significant differences were found in only four traits. In a Jomon sample very similar in composition to that used in this study, Hashimoto (2004) found great variation in most of the non-metric dental traits she investigated and insisted that the inter-local site variation could be attributed to genetically different sources between these sites. However, this variation could not be statistically corroborated in this study.

When subsuming the local sites into five regional groups significant differences were found for five traits, while the other 16 traits did not display any statistically significant 


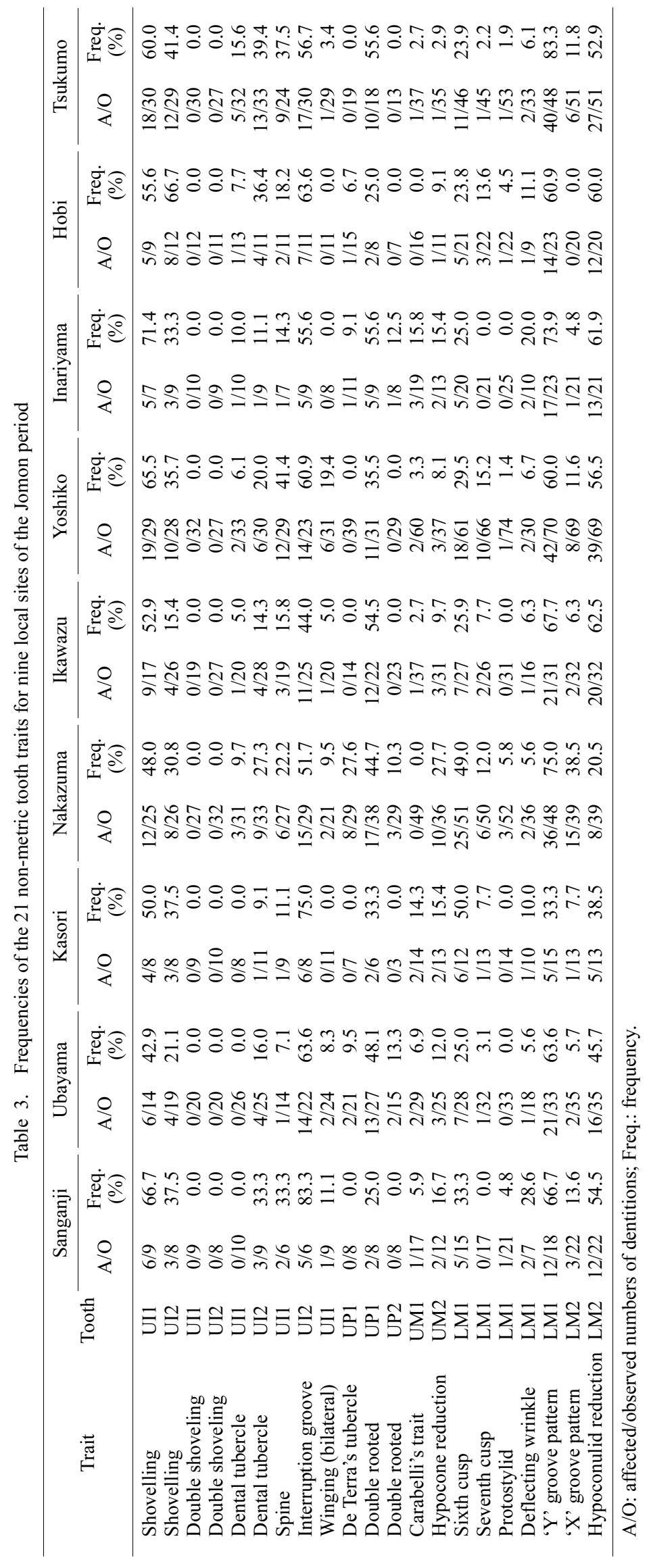


Table 4. Results of the chi-square tests of significance for the 21 non-metric tooth trait variation between the five Jomon local site series (Ubayama, Nakazuma, Ikawazu, Yoshiko and Tsukumo)

\begin{tabular}{lccccc}
\hline \multirow{2}{*}{ Trait } & \multicolumn{5}{c}{ Between the five local sites } \\
\cline { 2 - 6 } & Tooth & d.f. & \multicolumn{1}{c}{$\chi^{2}$} & \multicolumn{1}{c}{$p$} & \\
\hline Shovelling & UI1 & 4 & 2.946 & 0.567 & $\mathrm{~ns}$ \\
Shovelling & UI2 & 4 & 5.628 & 0.229 & $\mathrm{~ns}$ \\
Double shoveling & UI1 & 4 & 0.000 & 1.000 & $\mathrm{~ns}$ \\
Double shoveling & UI2 & 4 & 0.000 & 1.000 & $\mathrm{~ns}$ \\
Dental tubercle & UI1 & 4 & 5.467 & 0.243 & $\mathrm{~ns}$ \\
Dental tubercle & UI2 & 4 & 7.035 & 0.134 & $\mathrm{~ns}$ \\
Spine & UI1 & 4 & 8.612 & 0.072 & $\mathrm{~ns}$ \\
Interruption groove & UI2 & 4 & 2.365 & 0.669 & $\mathrm{~ns}$ \\
Winging (bilateral) & UI1 & 4 & 5.196 & 0.268 & $\mathrm{~ns}$ \\
De Terra's tubercle & UP1 & 4 & 20.967 & 0.000 & $* *$ \\
Double rooted & UP1 & 4 & 2.755 & 0.601 & $\mathrm{~ns}$ \\
Double rooted & UP2 & 4 & 7.943 & 0.094 & $\mathrm{~ns}$ \\
Carabelli's trait & UM1 & 4 & 3.230 & 0.520 & $\mathrm{~ns}$ \\
Hypocone reduction & UM2 & 4 & 11.775 & 0.019 & $*$ \\
Sixth cusp & LM1 & 4 & 9.445 & 0.051 & $\mathrm{~ns}$ \\
Seventh cusp & LM1 & 4 & 7.423 & 0.115 & $\mathrm{~ns}$ \\
Protostylid & LM1 & 4 & 5.090 & 0.278 & $\mathrm{~ns}$ \\
Deflecting wrinkle & LM1 & 4 & 0.044 & 1.000 & $\mathrm{~ns}$ \\
'Y' groove pattern & LM1 & 4 & 8.589 & 0.072 & $\mathrm{~ns}$ \\
'X' groove pattern & LM2 & 4 & 22.642 & 0.000 & $* *$ \\
Hypoconulid reduction & LM2 & 4 & 17.024 & 0.002 & $* *$ \\
& & & & & \\
\hline
\end{tabular}

d.f., degree of freedom; $p$, probability.

* Significant at the $5 \%$ level; ** significant at the $1 \%$ level; ns, not significant.

variation. The Hokkaido Jomon regional group is characterized by a high frequency of reduced hypocone size in the maxillary second molar. The Kanto Jomon group displays a relatively high frequency of the sixth cusp in the mandibular first molars, and a lower incidence of hypoconulid reduction in the second molars. The frequency of the ' $Y$ ' pattern in the first mandibular molars is highest in the Sanyo Jomon group, followed by the Tohoku, while the frequency of the ' $\mathrm{X}$ ' pattern in the second mandibular molars is variable among these regional groups. Thus the variation was found in only molar traits, while there is no significant difference in any anterior tooth trait.

The Smith's distances indicated that inter-regional variation within the Jomon population was less than that between any Jomon sample and other non-Jomon groups such as the Yayoi, Kofun, or Japanese. The close clustering of the five regional groups with the neighbor-joining analysis exhibits only a limited degree of non-metric dental variation among the five regional Jomon groups. The resultant un-rooted tree indicated an increased distance between the Hokkaido and Sanyo groups; this is to be expected based on their actual geographical distance. In a comparison of the pooled Jomon sample and the modern Japanese sample (Matsumura, 1995a), significant differences were found in 11 of 21 nonmetric dental traits, whereas only five traits varied among the regional Jomon groups.

Furthermore, the number of traits, geographically differentiated, decreases into only two traits in comparison between eastern and western Japanese populations. Clearly, based on the findings of this study, there is no basis on which to suggest such overall minor dental morphological variation is due to genetically different population origins of these two groups. The Jomon people should be regarded as relatively homogeneous, as hitherto proposed by various researchers based on cranial analyses (Ogata, 1981; Dodo, 1982; Yamaguchi, 1982; Mouri, 1986; Kondo, 1994).

The macro-regional comparison in the present study asserts the link of the Jomon to present-day Southeast Asians, nevertheless the sample was divided into eastern and

Table 5. Frequencies of the 21 non-metric dental traits for the five regional Jomon groups

\begin{tabular}{|c|c|c|c|c|c|c|c|c|c|c|c|}
\hline \multicolumn{2}{|l|}{ Population } & \multicolumn{2}{|c|}{ Hokkaido Jomon } & \multicolumn{2}{|c|}{ Tohoku Jomon } & \multicolumn{2}{|c|}{ Kanto Jomon } & \multicolumn{2}{|c|}{ Tokai Jomon } & \multicolumn{2}{|c|}{ Sanyo Jomon } \\
\hline Trait & Tooth & $\mathrm{A} / \mathrm{O}$ & Freq. $(\%)$ & $\mathrm{A} / \mathrm{O}$ & Freq. $(\%)$ & $\mathrm{A} / \mathrm{O}$ & Freq. $(\%)$ & $\mathrm{A} / \mathrm{O}$ & Freq. $(\%)$ & $\mathrm{A} / \mathrm{O}$ & Freq. $(\%)$ \\
\hline Shovelling & UI1 & $9 / 17$ & 52.9 & $13 / 20$ & 65.0 & $28 / 47$ & 59.6 & $15 / 21$ & 71.4 & $6 / 10$ & 60.0 \\
\hline Shovelling & UI2 & $10 / 23$ & 43.5 & $9 / 26$ & 34.6 & $32 / 86$ & 37.2 & $36 / 87$ & 41.4 & $10 / 26$ & 38.5 \\
\hline Double shoveling & UI1 & $0 / 26$ & 0.0 & $0 / 27$ & 0.0 & $0 / 78$ & 0.0 & $1 / 88$ & 1.1 & $0 / 34$ & 0.0 \\
\hline Double shoveling & UI2 & $0 / 22$ & 0.0 & $0 / 23$ & 0.0 & $0 / 88$ & 0.0 & $0 / 86$ & 0.0 & $0 / 29$ & 0.0 \\
\hline Dental tubercle & UI1 & $1 / 25$ & 4.0 & $3 / 28$ & 10.7 & $5 / 88$ & 5.7 & $6 / 91$ & 6.6 & $6 / 37$ & 16.2 \\
\hline Dental tubercle & UI2 & $5 / 22$ & 22.7 & $8 / 26$ & 30.8 & $20 / 95$ & 21.1 & $15 / 89$ & 16.8 & $13 / 36$ & 36.1 \\
\hline Spine & UI1 & $8 / 22$ & 36.4 & $6 / 20$ & 30.0 & $12 / 71$ & 16.9 & $20 / 75$ & 26.7 & $10 / 28$ & 35.7 \\
\hline Interruption groove & UI2 & $8 / 19$ & 42.1 & $12 / 18$ & 66.7 & $56 / 93$ & 60.2 & $39 / 69$ & 56.5 & $19 / 32$ & 59.4 \\
\hline Winging (bilateral) & UI1 & $4 / 23$ & 17.4 & $5 / 25$ & 20.0 & $5 / 70$ & 7.1 & $7 / 80$ & 8.8 & $1 / 33$ & 3.0 \\
\hline De Terra's tubercle & UP1 & $4 / 28$ & 14.3 & $2 / 30$ & 6.7 & $14 / 79$ & 17.7 & $13 / 85$ & 15.3 & $0 / 23$ & 0.0 \\
\hline Double rooted & UP1 & $7 / 15$ & 46.7 & $6 / 24$ & 25.0 & $47 / 99$ & 47.5 & $33 / 76$ & 43.4 & $13 / 24$ & 54.2 \\
\hline Double rooted & UP2 & $0 / 12$ & 0.0 & $0 / 23$ & 0.0 & $5 / 69$ & 7.2 & $1 / 76$ & 1.3 & $0 / 20$ & 0.0 \\
\hline Carabelli's trait & UM1 & $1 / 28$ & 3.6 & $3 / 56$ & 5.4 & $7 / 128$ & 5.5 & $7 / 149$ & 4.7 & $2 / 52$ & 3.8 \\
\hline Hypocone reduction & UM2 & $8 / 24$ & 33.3 & $3 / 25$ & 12.0 & $11 / 87$ & 12.6 & $10 / 93$ & 10.8 & $1 / 41$ & 2.4 \\
\hline Sixth cusp & LM1 & $5 / 36$ & 13.9 & $9 / 47$ & 19.1 & $52 / 124$ & 41.9 & $40 / 150$ & 26.6 & $16 / 69$ & 23.2 \\
\hline Seventh cusp & LM1 & $3 / 35$ & 8.6 & $3 / 42$ & 7.1 & $9 / 126$ & 7.1 & $7 / 158$ & 4.6 & $1 / 69$ & 1.4 \\
\hline Protostylid & LM1 & $1 / 38$ & 2.6 & $2 / 61$ & 3.3 & $7 / 136$ & 5.1 & $7 / 177$ & 3.9 & $7 / 81$ & 8.7 \\
\hline Deflecting wrinkle & LM1 & $4 / 16$ & 25.0 & $4 / 21$ & 19.0 & $3 / 56$ & 5.4 & $3 / 30$ & 10.0 & $2 / 17$ & 11.8 \\
\hline 'Y' groove pattern & LM1 & $25 / 36$ & 69.4 & $41 / 54$ & 75.9 & $82 / 130$ & 63.1 & $108 / 171$ & 63.0 & $62 / 73$ & 84.9 \\
\hline ' $X$ ' groove pattern & LM2 & $8 / 39$ & 20.5 & $8 / 58$ & 13.8 & $30 / 121$ & 24.8 & $14 / 164$ & 8.6 & $9 / 73$ & 12.3 \\
\hline Hypoconulid reduction & LM2 & $17 / 31$ & 54.8 & $25 / 49$ & 51.0 & $20 / 74$ & 27.0 & $30 / 68$ & 44.1 & $14 / 33$ & 42.4 \\
\hline
\end{tabular}

A/O: affected/observed numbers of dentitions; Freq.: frequency. 
Table 6. Results of the chi-square tests of significance for the 21 non-metric dental trait variation between the five regional Jomon groups (Hokkaido, Tohoku, Kanto, Tokai and Sanyo)

\begin{tabular}{lccccc}
\hline \multicolumn{1}{c}{ Trait } & Tooth & d.f. & $\chi^{2}$ & $p$ & \\
\hline Shovelling & UI1 & 4 & 1.588 & 0.811 & $\mathrm{~ns}$ \\
Shovelling & UI2 & 4 & 0.728 & 0.948 & $\mathrm{~ns}$ \\
Double shoveling & UI1 & 4 & 1.882 & 0.757 & $\mathrm{~ns}$ \\
Double shoveling & UI2 & 4 & 0.000 & 1.000 & $\mathrm{~ns}$ \\
Dental tubercle & UI1 & 4 & 5.206 & 0.267 & $\mathrm{~ns}$ \\
Dental tubercle & UI2 & 4 & 6.522 & 0.163 & $\mathrm{~ns}$ \\
Spine & UI1 & 4 & 5.850 & 0.211 & $\mathrm{~ns}$ \\
Interruption groove & UI2 & 4 & 2.800 & 0.592 & $\mathrm{~ns}$ \\
Winging (bilateral) & UI1 & 4 & 6.967 & 0.138 & $\mathrm{~ns}$ \\
De Terra's tubercle & UP1 & 4 & 6.256 & 0.181 & $\mathrm{~ns}$ \\
Double rooted & UP1 & 4 & 5.021 & 0.285 & $\mathrm{~ns}$ \\
Double rooted & UP2 & 4 & 6.717 & 0.152 & $\mathrm{~ns}$ \\
Carabelli's trait & UM1 & 4 & 0.358 & 0.986 & $\mathrm{~ns}$ \\
Hypocone reduction & UM2 & 4 & 13.831 & 0.008 & $* *$ \\
Sixth cusp & LM1 & 4 & 17.919 & 0.001 & $* *$ \\
Seventh cusp & LM1 & 4 & 4.122 & 0.390 & $\mathrm{~ns}$ \\
Protostylid & LM1 & 4 & 3.576 & 0.466 & $\mathrm{~ns}$ \\
Deflecting wrinkle & LM1 & 4 & 6.217 & 0.183 & $\mathrm{~ns}$ \\
'Y' groove pattern & LM1 & 4 & 14.571 & 0.006 & $* *$ \\
'X' groove pattern & LM2 & 4 & 15.728 & 0.003 & $* *$ \\
Hypoconulid reduction & LM2 & 4 & 10.684 & 0.030 & $*$ \\
\hline
\end{tabular}

d.f., degree of freedom.

* Significant at the $5 \%$ level; $* *$ significant at the $1 \%$ level; ns, not significant.

western Jomon. The origin of the Jomon people is not the major focus in this study; this macro-regional comparison was made in order to assess the level of inter-regional difference in the Jomon sample. However, it may be worth commenting on this issue. The origin of the Jomon people is complicated by the variety of different research methods that have been used. Some cranial and dental studies have led researchers to posit that these populations derived from Southeast Asia (Turner, 1976, 1989, 1990, 1992; Hanihara, 1990, 1992a, b, 1993; Matsumura, 1994, 1995b, 2000a, b; Matsumura and Hudson, 2005) and mitocondorial DNA analysis (Horai et al., 1991), while other studies based on genetic comparisons have suggested a Northeast Asian origin (Omoto, 1995; Omoto and Saitou, 1997; Oota et al., 1999). In the meantime, the distinctiveness of their non-metric cranial traits has obscured the possible ancestry of the Jomon (Shigematsu et al., 2004). Although the present study confirms a somewhat parallel dental morphology between

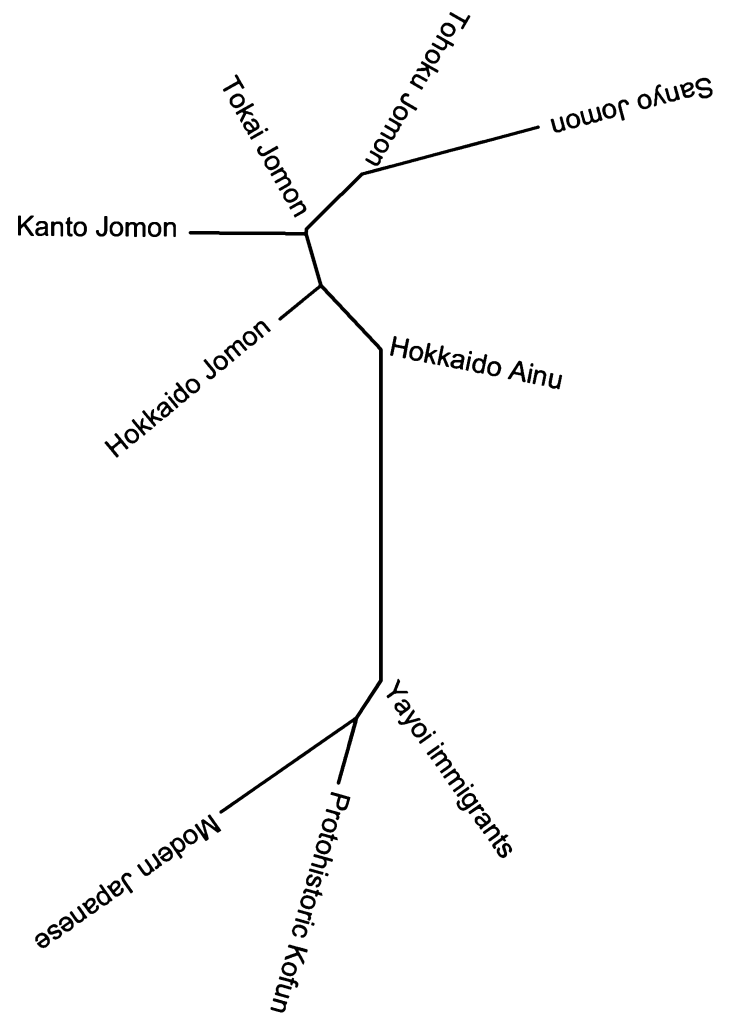

Figure 2. A tree of the five regional Jomon groups and other chronological samples by the neighbor-joining method applied to the matrix of the Smith's distances of Table 7.

the Jomon and modern Southeast Asians, this does not necessarily suggest a single genetic origin for the Jomon, because most the present-day Southeast Asians may have hybridized with Northeast Asians including Chinese (Matsumura and Hudson, 2005). The present study also supports this view: the un-rooted tree (Figure 3 ) positioned modern Southeast Asians connecting with the Jomon in between Northeast Asians and prehistoric Southeast Asians. The samples used in the present study were middle to latest Jomon period (2300-5000 BP), i.e. approximately 7000 years had passed since the beginning of the Jomon era (ca. 12000 BP). Taking this missing time into consideration, it is not impossible that the ancestry of the Jomon group arose through the diffusion of Northeast Asians early or

Table 7. Smith's distances between the five regional Jomon groups and four different chronological groups, based on frequencies of the 21 non-metric dental traits

\begin{tabular}{|c|c|c|c|c|c|c|c|c|}
\hline & $\begin{array}{c}\text { Hokkaido } \\
\text { Jomon }\end{array}$ & Tohoku Jomon & Kanto Jomon & Tokai Jomon & Sanyo Jomon & $\begin{array}{c}\text { Yayoi } \\
\text { immigrants }\end{array}$ & $\begin{array}{c}\text { Protohistoric } \\
\text { Kofun }\end{array}$ & $\begin{array}{l}\text { Modern } \\
\text { Japanese }\end{array}$ \\
\hline Tohoku Jomon & 0.0206 & & & & & & & \\
\hline Kanto Jomon & 0.0750 & 0.0611 & & & & & & \\
\hline Tokai Jomon & 0.0263 & 0.0147 & 0.0238 & & & & & \\
\hline Sanyo Jomon & 0.0905 & 0.0447 & 0.0932 & 0.0574 & & & & \\
\hline Yayoi immigrants & 0.1290 & 0.1383 & 0.1445 & 0.1190 & 0.2203 & & & \\
\hline Protohistoric Kofun & 0.1595 & 0.1868 & 0.1716 & 0.1404 & 0.2771 & 0.0119 & & \\
\hline Modern Japanese & 0.1741 & 0.2374 & 0.1989 & 0.1612 & 0.3115 & 0.0737 & 0.0629 & \\
\hline Hokkaido Ainu & 0.0364 & 0.0615 & 0.0517 & 0.0352 & 0.1195 & 0.1059 & 0.1232 & 0.0983 \\
\hline
\end{tabular}


Table 8. Frequencies of the 21 non-metric dental traits in the Eastern and Western Jomon samples and results of the chi-square tests for the differences between the two groups

\begin{tabular}{|c|c|c|c|c|c|c|c|c|}
\hline \multirow{2}{*}{ Trait } & \multirow{2}{*}{ Tooth } & \multicolumn{2}{|c|}{ Eastern Jomon } & \multicolumn{2}{|c|}{ Western Jomon } & \multirow{2}{*}{$\chi^{2}$} & \multirow{2}{*}{$p$} & \\
\hline & & $\mathrm{A} / \mathrm{O}$ & Freq. $(\%)$ & $\mathrm{A} / \mathrm{O}$ & Freq. $(\%)$ & & & \\
\hline Shovelling & UI1 & $50 / 84$ & 59.5 & $21 / 31$ & 67.7 & 0.647 & 0.421 & ns \\
\hline Shovelling & UI2 & $51 / 135$ & 37.8 & $46 / 113$ & 40.7 & 0.222 & 0.638 & ns \\
\hline Double shoveling & UI1 & $0 / 131$ & 0.0 & $1 / 122$ & 0.8 & 1.078 & 0.299 & ns \\
\hline Double shoveling & UI2 & $0 / 133$ & 0.0 & $0 / 115$ & 0.0 & 0.000 & 1.000 & ns \\
\hline Dental tubercle & UI1 & $9 / 141$ & 6.4 & $12 / 128$ & 9.4 & 0.835 & 0.361 & ns \\
\hline Dental tubercle & UI2 & $33 / 143$ & 23.1 & $28 / 125$ & 22.4 & 0.002 & 0.895 & ns \\
\hline Spine & UI1 & $26 / 113$ & 23.0 & $30 / 103$ & 29.1 & 1.050 & 0.306 & ns \\
\hline Interruption groove & UI2 & $76 / 130$ & 58.5 & $58 / 101$ & 57.4 & 0.026 & 0.874 & ns \\
\hline Winging (bilateral) & UI1 & $14 / 118$ & 11.9 & $8 / 113$ & 7.1 & 1.534 & 0.216 & ns \\
\hline De Terra's tubercle & UP1 & $20 / 137$ & 14.6 & $13 / 108$ & 12.0 & 0.340 & 0.560 & ns \\
\hline Double rooted & UP1 & $60 / 138$ & 43.5 & $46 / 100$ & 46.0 & 0.149 & 0.699 & ns \\
\hline Double rooted & UP2 & $5 / 104$ & 4.8 & $1 / 96$ & 1.0 & 2.433 & 0.119 & ns \\
\hline Carabelli's trait & UM1 & $11 / 212$ & 5.2 & $9 / 201$ & 4.5 & 0.113 & 0.737 & ns \\
\hline Hypocone reduction & UM2 & $22 / 136$ & 16.2 & $11 / 134$ & 8.2 & 3.994 & 0.046 & $*$ \\
\hline Sixth cusp & LM1 & $66 / 207$ & 31.9 & $56 / 219$ & 25.6 & 2.675 & 0.150 & ns \\
\hline Seventh cusp & LM1 & $15 / 203$ & 7.4 & $8 / 227$ & 3.5 & 3.162 & 0.075 & ns \\
\hline Protostylid & LM1 & $10 / 235$ & 4.3 & $14 / 258$ & 5.4 & 0.364 & 0.546 & ns \\
\hline Deflecting wrinkle & LM1 & $11 / 93$ & 11.8 & $5 / 47$ & 10.6 & 0.044 & 0.835 & ns \\
\hline 'Y' groove pattern & LM1 & $148 / 219$ & 67.6 & $170 / 244$ & 69.7 & 0.235 & 0.628 & ns \\
\hline ' $\mathrm{X}$ ' groove pattern & LM2 & $46 / 218$ & 21.1 & $23 / 237$ & 9.7 & 11.463 & 0.001 & $* *$ \\
\hline Hypoconulid reduction & LM2 & $62 / 154$ & 40.3 & $44 / 101$ & 43.6 & 0.274 & 0.601 & ns \\
\hline
\end{tabular}

A/O: affected/observed numbers of dentitions; Freq.: frequency.

* Significant at the $5 \%$ level; ** significant at the $1 \%$ level; ns, not significant.

Table 9. Smith's distances between the two Jomon samples and comparative macro-regional samples from East Asia and Pacific, based on frequencies of the 21 non-metric dental traits

\begin{tabular}{|c|c|c|c|c|c|c|c|c|c|}
\hline & $\begin{array}{l}\text { Eastern } \\
\text { Jomon }\end{array}$ & $\begin{array}{l}\text { Western } \\
\text { Jomon }\end{array}$ & $\begin{array}{l}\text { Hokkaido } \\
\text { Ainu }\end{array}$ & $\begin{array}{l}\text { Prehistoric } \\
\text { SE-Asians }\end{array}$ & $\begin{array}{l}\text { Island SE- } \\
\text { Asians }\end{array}$ & $\begin{array}{l}\text { Mainland } \\
\text { SE-Asians }\end{array}$ & $\begin{array}{c}\text { Andaman } \\
\text { Islanders }\end{array}$ & $\begin{array}{l}\text { Australo- } \\
\text { Melanesians }\end{array}$ & $\begin{array}{c}\text { Early and } \\
\text { Modern } \\
\text { Japanese }\end{array}$ \\
\hline Western Jomon & 0.0112 & & & & & & & & \\
\hline Hokkaido Ainu & 0.0378 & 0.0425 & & & & & & & \\
\hline Prehistoric Southeast Asians & 0.0953 & 0.1226 & 0.1454 & & & & & & \\
\hline Island Southeast Asians & 0.0837 & 0.1205 & 0.0865 & 0.0512 & & & & & \\
\hline Mainland Southeast Asians & 0.0809 & 0.0984 & 0.0882 & 0.0850 & 0.0341 & & & & \\
\hline Andaman Islanders & 0.1943 & 0.1980 & 0.3071 & 0.0734 & 0.2245 & 0.2070 & & & \\
\hline Australo-Melanesians & 0.1232 & 0.1317 & 0.2018 & 0.0509 & 0.0947 & 0.0673 & 0.1138 & & \\
\hline Early and Modern Japanese & 0.1381 & 0.1479 & 0.0990 & 0.2076 & 0.1359 & 0.0556 & 0.3703 & 0.1790 & \\
\hline Northeast Asians & 0.2006 & 0.2112 & 0.1366 & 0.2391 & 0.1541 & 0.0599 & 0.3553 & 0.2026 & 0.0534 \\
\hline
\end{tabular}

prior to the Jomon period and had been homogenized by the middle Jomon stage. Although few human remains from the earlier half of the Jomon period have been found, morphological variation, including skeletal gracility and robustness, was discovered among several specimens (e.g. Ogata, 1981; Yamaguchi, 1992; Nakahashi, 2005). Whether such heterogeneity is due to differences in environmental condition or has a genetic origin is still a matter of conjecture. To address the issue of the Jomon origin, more findings of earlier Jomon skeletons from northern and southern Japan are needed.

\section{Acknowledgments}

The author is indebted to Professor Toyohiro Nishimoto, National History Museum, and Professor Yukio Dodo, Tohoku University for their permission to investigate additional Jomon specimens from the Funadomari, Nakazuma,
Shimohta, and Usumoshiri sites in their charge. Permission to examine other samples in other institutions has been previously acknowledged (Matsumura, 1989, 1994, 1995b).

Thanks are also due to Dr Marc F. Oxenham, Australian National University, for manuscript correction.

This study is supported in part by a Grant-in-Aid in 2004 (No. 14540664) and 2005 (No. 15405018) from the Japan Society for the Promotion of Science.

\section{References}

Berry A.C. and Berry R.J. (1967) Epigenetic variation in the human cranium. Journal of Anatomy, 101: 361-379.

Brace C.L. and Nagai M. (1982) Japanese tooth size: past and present. American Journal of Physical Anthropology, 59: 399-411.

Dodo Y. (1982) A metric analysis of Jomon crania from the Tohoku district. Journal of the Anthropological Society Nip- 


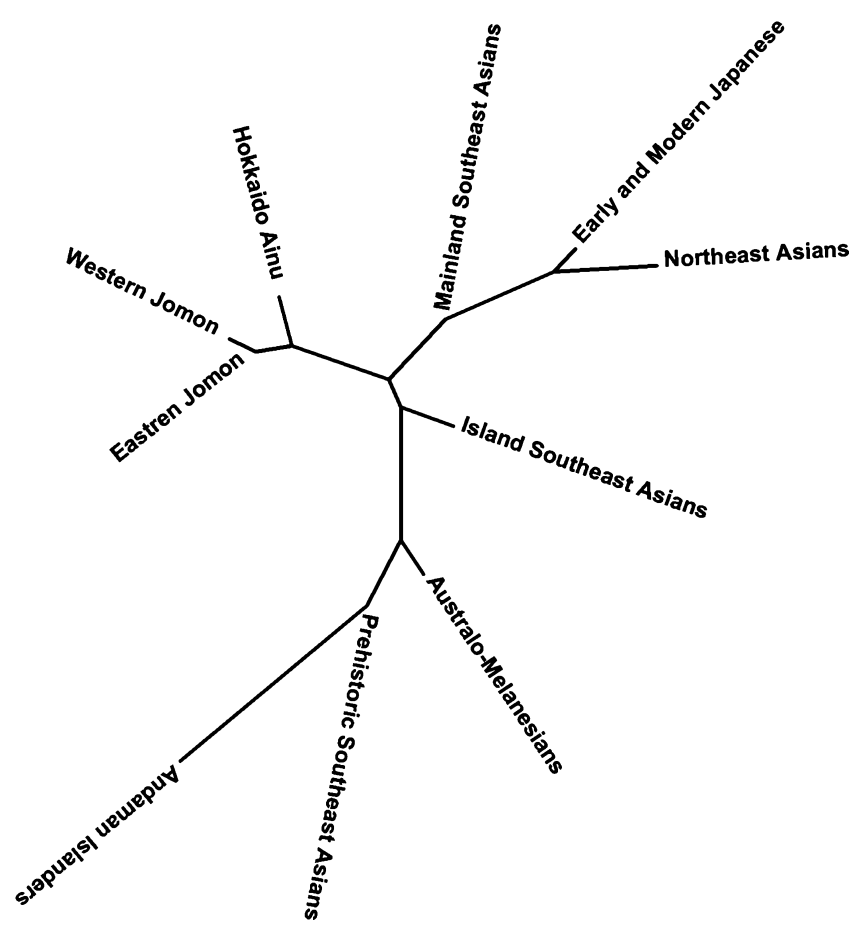

Figure 3. A tree of the eastern and western Jomon groups and other macro-regional East Asian and Pacific samples by the neighborjoining method applied to the matrix of the Smith's distances of Table 9.

pon, 90(Supplement): 119-128 (in Japanese with English summary).

Dodo Y. (1986) Metrical and non-metrical analyses of Jomon crania from eastern japan. In: Akazawa T. and Aikens C.M. (eds.), Prehistoric Hunter-gatherers in Japan. Bulletin of the University Museum of the University of Tokyo, 27: 137-161.

Dodo Y. and Ishida H. (1990) Population history of Japan as viewed from cranial nonmetric variation. Journal of the Anthropological Society Nippon, 98: 269-287.

Ehara A., Matsumoto S., and Kinoshita M. (1985) Skeletal morphology. [Shutudo-jinkotsu no keishitsu.] In: Atsumi-cho Board of Education (ed.), The Ikawazu Site. [Ikawazu-Iseki.] Aatsumicho Maizou-Bunkazai Chousa-Houkokusho vol. 4, Atsumi-cho Board of Education, Atsumi, pp. 343-394 (in Japanese).

Hanihara K. (1976) Statistical and comparative studies of the Australian aboriginal dentition. Bulletin of the University Museum of the University of Tokyo, 11: 1-57.

Hanihara K. (1985) Origins and affinities of Japanese as viewed from cranial measurements. In: Kirk R. and Szathmary E. (eds.), Out of Asia: Peopling the Americas and the Pacific. The Journal of Pacific History, Canberra, pp. 105-112.

Hanihara K. (1991) Dual structure model for the population history of the Japanese. Japan Review, 2: 1-33.

Hanihara K., Suzuki T., Uchida A., Matsumura H., Dodo Y., and Baba H. (1983) Human remains from Sanganji shellmounds. [Sanganji kaizuka shutsudo jinkotsu.] Bulletin of the Fukushima Prefecture Museum, 17: 413-494 (in Japanese).

Hanihara T. (1990) Affinities of the Philippine Negritos with Japanese and the Pacific populations I. Journal of the Anthropological Society of Nippon, 98: 13-27.

Hanihara T. (1992a) Dental and cranial affinities among the populations in East Asia and the Pacific: the basic populations in East Asia, IV. American Journal of Physical Anthropology,
88: $163-182$.

Hanihara T. (1992b) Negritos, Australian Aborigines, and the "Proto-Sundadont" dental pattern: the basic populations in East Asia, V. American Journal of Physical Anthropology, 88: 183-196.

Hanihara T. (1993) Craniofacial features of Southeast Asians and Jomonese: a reconsideration of their microevolution since the late Pleistocene. Anthropological Science, 101: 25-46.

Hashimoto H. (2004) Geographical and temporal variation in nonmetrical dental traits among the Jomon people from the mainland Japan. Anthropological Science, 112: 296.

Hirata K. and Hoshino K. (2003) Report on human remains from Shimohta shell-mounds. [Shimohta kaizuka shutudo jinkotsu houkokusho.] In: Sounan-Bunkazai Center (ed.), Shimohta Shell-Mounds. [Shimohta-Kaizuka.] Chibaken Mobara Tochi-Kairyo Jimusho, Mobara City, and Sounan-Bunkazai Center, Mobara, pp. 1-182 (in Japanese).

Horai S., Kondo R., Murayama K., Hayashi S., Koike H., and Nakai N. (1991) Phylogenetic affiliation of ancient and contemporary humans inferred from mitochondorial DNA. Philosophical Transactions of the Royal Society of London, 333: 409-417.

Howells W.W. (1966) The Jomon population of Japan: a study by discriminant analysis of Japanese and Ainu crania. Papers of the Peabody Museum of Archaeology and Ethnology, Harvard University, 57: 1-43.

Kintaka K. (1928) Anthropologische Untersuchungen über das Skelett der Yoshiko-Steinzeitmenschen. Journal of the Anthropological Society of Nippon, 43(Supplement): 497736 (in Japanese with German title).

Kiyono K. and Miyamoto H. (1926) Anthropologische Untersuchungen über das Skelett der Tsukumo-Steinzeitmenschen. Journal of the Anthropological Society of Nippon, 41: 95140, 151-208 (in Japanese with German title).

Koganei Y. (1932). Human skeletal remains from the Ubayama sell-mounds. [Ubayama-kaizuka no jinkotsu.] Papers Anthropological Institution, Faculty of Science, the Imperial University of Tokyo, 5: 61-68 (in Japanese).

Kondo M. and Matsu'ura S. (2005) Dating of the hamakita human remains from Japan. Anthropological Science, 113: 15-161.

Kondo O. (1993) Skulls of Ubayama shell-mounds I. Morphological description and univariate comparison. Anthropological Science, 101: 307-331.

Kondo O. (1994) The skulls of Ubayama shell-mounds II. An analysis of intra-and inter-regional variation of the Jomon population. Anthropological Science, 102: 59-74.

Matsumura H. (1989) Geographical variation of dental measurements in the Jomon population. Journal of the Anthropological Society Nippon, 97: 493-512.

Matsumura H. (1990) Geographical variation of dental characteristics in the Japanese of the protohistoric Kofun period. Journal of the Anthropological Society Nippon, 98: 439-449.

Matsumura H. (1994) A microevolutional history of Japanese people from dental characteristics perspective. Anthropological Science, 102: 93-118.

Matsumura H. (1995a) Human skeletal remains. [Jinkotsu shoken.] In: Nakazuma Kaizuka Hakkutsu Chosadan (ed.), The Nakazuma Shell-mounds. [Nakazuma Kaizuka.] Toride City Board of Education, Toride, pp. 130-204 (in Japanese).

Matsumura H. (1995b) Dental characteristics affinities of the prehistoric to the modern Japanese with the East Asians, American natives and Australo-Melanesians. Anthropological Science, 103: 235-261.

Matsumura H. (2000a) Dental metric variations between the periods, sites and individuals of the Neolithic Jomon people in the Setouchi, Tokai and Kanto regions, Japan. Memoirs of the National Science Museum, Tokyo, 32: 175-187 (in Japanese with English summary).

Matsumura H. (2000b) Comparative study of the crown cusp areas 
in the maxillary second molars of the Jomon people. Bulletin of the National Science Museum, Tokyo, D26: 31-38.

Matsumura H. (2006) The population history of Southeast Asia viewed from morphometric analyses of human skeletal and dental remains. In: Oxenham M. and Tayles N. (eds.), Bioarchaeology of Southeast Asia. Cambridge University Press, Cambridge, pp. 33-58.

Matsumura H. and Hudson M.J. (2005) Dental perspectives on the population history of Southeast Asia. American Journal of Physical Anthropology, 127: 182-209.

Matsumura H., Anezaki T., and Ishida H. (2001) A morphometric analysis of Jomon skeletons from the Funadomari site on Rebun Island, Hokkaido, Japan. Anthropological Science, 109: 1-21.

Mizushima I., Kuwamura K., and Suwa G. (2004) Database of Jomon period skeletal remains. 2) Ubayama. The University Museum, The University of Tokyo, Material Reports No. 54.

Mizushima I., Saso A., Kubo D., and Suwa G. (2006) Database of Jomon period skeletal remains. 3) Chiba Prefecture (Horinouchi, Kasori, Soya, etc.). The University Museum, The University of Tokyo, Material Reports No. 61.

Mouri T. (1986) Incidences of cranial nonmetric characters in five Jomon populations from west Japan. Journal of the Anthropological Society Nippon, 96: 319-337.

Nakahashi T. (2005) Origin of Japanese. [Nihonjin no Kigen.] Koudansha, Tokyo (in Japanese).

Ogata T. (1981) The human skeletons of Jomon period. [Jomon jidai jinkotsu.] In: Ogata T. (ed.), The Japanese 1. Anthropology, Vol. 5. Yuzankaku, Tokyo, pp. 27-56 (in Japanese).

Omoto K. (1995) Genetic diversity and the origins of the "Mongoloids". In: Brenner S. and Hanihara K. (eds.), The Origin and Past of Modern Humans as Viewed from DNA. World Scientific, Singapore, pp. 92-109.

Omoto K. and Saitou N. (1997) Genetic origins of the Japanese: a partial support for the "dual structure hypothesis". American Journal of Physical Anthropology, 102: 437-446.

Oota H., Saitou N., Matsushita T., and Ueda S. (1999) Molecular genetic analysis of remains of a 2,000-year-old human population in China- and its relevance for the origin of the modern Japanese population. American Journal of Human Genetics, 64: $250-258$

Ossenberg N.S., Dodo Y., Maeda T., and Kawakubo Y. (2006) Ethnogenesis and craniofacial change in Japan from the perspective of nonmetric traits. Anthropological Science, 114: 99115 .

Pietrusewsky M. (1994) Pacific-Asian relationships: a physical anthropological perspective. Oceanic Linguistics, 33: 407429.

Pietrusewsky M. (2004) Multivariate comparisons of female cranial series from the Ryukyu Islands and Japan. Anthropological Science, 112: 199-211.
Saitou N. and Nei M. (1987) The neighbor-joining method: a new method for reconstructing phylogenetic trees. Molecular Biology and Evolution, 4: 406-425.

Shigematsu M., Ishida H., Goto M., and Hanihara T. (2004) Morphological affinities between Jomon and Ainu: reassessment based on nonmetric cranial traits. Anthropological Science, 112: $61-72$.

Suwa G., Mizushima I., and Sakaue K. (2003) Database of Jomon period skeletal remains. 1) Hobi. The University Museum, The University of Tokyo, Material Reports No. 52.

Suzuki H., Kimura T., and Baba H. (1968) Human remains excavated from the Kasori shell-mounds. [Kasori-kaizuka hakkutsu no jinkotsu.] In: Kasori-Kaizuka Chosadan (ed.), Kasoiminami Shell-Mounds II. [Kasoriminami Kaizuka II.] Chuokouron-Bijutsu, Tokyo, pp. 206-225 (in Japanese).

Suzuki H., Endo B., and Terasawa T. (1972). Human remains from Ikawazu shell-mounds in Aichi Prefecture. [Aichiken Ikawazu-kaizuka no jinkotsu.] In: Atsumi-cho Board of Education (ed.), Ikawazu Shell-Mounds. Ikawazu-Kaizuka.] Atsumi-cho Education Board of Atsumi-cho, pp. 171-179 (in Japanese).

Turner C.G. II (1976) Dental evidence on the origin of the Ainu and Japanese. Science, 193: 911-913.

Turner C.G. II (1989) Teeth and prehistory in Asia. Scientific American, 260: 70-77.

Turner C.G. II (1990) Major features of Sundadonty and Sinodonty, including suggestions about East Asian microevolution, population history and late Pleistocene relationships with Australian Aborigines. American Journal of Physical Anthropology, 82: 295-317.

Turner C.G. II (1992) Microevolution of East Asian and European populations: a dental perspective. In: Akazawa T., Aoki K. and Kimura T. (eds.), The Evolution and Dispersal of Modern Humans in Asia. Hokusensha, Tokyo, pp. 415-438.

Turner C.G. II, Nichol C.R., and Scott G.R. (1991) Scoring procedures for key morphological traits of the permanent dentition: The Arizona State University dental anthropology system. In Kelly M.A. and Larsen C.S. (eds.), Advances in Dental Anthropology. Wiley-Liss, New York, pp. 13-31.

Yamaguchi B. (1982) A review of the osteological characteristics of the Jomon population in prehistoric Japan. Journal of the Anthropological Society Nippon 90(Supplement): 77-90.

Yamaguchi B. (1992) Skeletal morphology of the Jomon people. In: Hanihara K. (ed.), Japanese as a Member of the Asian and Pacific Populations. International Research Center for Japanese Studies, Kyoto, pp. 53-63.

Yoneda M., Saso A., Suzuki R., Shibata Y., Morita M., Suwa G., and Akazawa T. (2005) Chronology of the Yayoi skeletal remains from the Kanto district: a preliminary re-evaluation by radiocarbon dating of postcranial material. Anthropological Science, 113: 169-182. 